\section{THE EFFECTS OF DIFFERENT PH AND SALINITIES ON GROWTH RATE AND CARRAGEENAN YIELD OF GRACILARIA MANILAENSIS}

Nor Salamah Mohamad Hidayata, Normawaty MohammadNoorb*, Deny Susantic, Shahbudin Saadb, Yukinori Mukaib

aDepartment of Biotechnology, Kuliyyah of Science, International Islamic University Malaysia, Jalan Sultan Ahmad Shah, Bandar Indera Mahkota, 25200 Kuantan, Pahang, Malaysia

bDepartment of Marine Science, Kuliyyah of Science, International Islamic University Malaysia, Jalan Sultan Ahmad Shah, Bandar Indera Mahkota, 25200 Kuantan, Pahang, Malaysia

cDepartment of Chemistry, Kuliyyah of Science, International Islamic University Malaysia, Jalan Sultan Ahmad Shah, Bandar Indera Mahkota, 25200 Kuantan, Pahang, Malaysia
Article history

Received

26 June 2015

Received in revised form

18 September 2015

Accepted

22 October 2015

*Corresponding author normahwaty@iium.edu.my

\begin{abstract}
The high demand of seaweed for their polysaccharide namely carrageenan leads to the commercial production of carrageenophytes through mariculture. Based on literatures it is well documented that growth rate and carrageenan yield depend on environmental factors such as salinity, $\mathrm{pH}$, temperatures, light intensity and water movement. In this study, growth rate and carrageenan yield of Gracilaria manilaensis, a red seaweed, was determined at different $\mathrm{pH}$ and salinities. $\mathrm{G}$. manilaensis was cultured under laboratory conditions in a $500 \mathrm{~mL}$ flask at different salinities ( $15 \mathrm{psu}, 20 \mathrm{psu}$ and $25 \mathrm{psu}$ ) and pH (7.6, 7.8, and 8.0) for 21 days. At the end of experiment, the growth rate was determined followed by carrageenan analysis. From the analysis, growth rate was highest at salinity of $15 \mathrm{psu}$ and $\mathrm{pH} 7.6$ with $1.3 \pm 0.2 \%$ day-1. For carrageenan analysis, the seaweed was air dried for about a week until it reached a constant weight. Farmed G. manilaensis was used as control and carrageenan yield was determined from farmed G. manilaensis. It gives yield of $50.2 \pm 10.9 \%$. For carrageenan yield analysis, the highest value was demonstrated at salinity of $25 \mathrm{psu}$ and $\mathrm{pH} 8.0$ with $91.7 \pm 14.4 \%$. Result shows that carrageenan yields from G. manilaensis under laboratory conditions are higher compared to farmed Gracillaria. This indicates that the quality of G. manilaensis in term of carrageenan content can be optimized under certain growth conditions. This is important as this species has the potential to be commercialized for pharmaceutical and food industries.
\end{abstract}

Keywords: Mariculture, Gracilaria manilaensis, pH, light intensity, growth rate, carrageenan yield

(C) 2015 Penerbit UTM Press. All rights reserved

\subsection{INTRODUCTION}

Red seaweed is well known for their production of phycocolloids especially carrageenan which is economically important and can be commercialized. Carrageenans from this type of seaweed been widely used in various applications such as in food, medicine, pharmaceutical, research, cosmetics and industrial. In food industry, they are used as gelling, thickening, stabilizing agents and food additives [1]. In medicinal and pharmaceuticals industries, they have been extensively investigated for their immense range of bioactivities such as antiviral, anticoagulant, antitumoral, antioxidant, 
anticoagulant and immunomudulatory activities as well as stabilizing agents for medication [2, 3]. In research industry, carrageenans act as a culture medium for plants and microorganism and other biotechnology applications while in cosmetics industry is it used for formulation of products including hair conditioner and cleansing products [1, 4]. Even though seaweed cultivation for carrageenan has been recorded in several countries including the Philippines, Indonesia and Malaysia, the production of seaweed as raw material for carrageenan industry is still limited $[5,6]$.

The increased of market demand for raw seaweed initiates research and development efforts for cultivation of some species mainly the economically commercialized species. Cultivation of seaweed has become one of the alternatives to fulfill the demand. The cultivation effort gives great influenced in the biomass yield and biochemical composition of the seaweed [7]. In natural marine ecosystem, subtle changes in physical and chemical aspects will influence seaweed ecology. They are susceptible with environmental changes which occurs naturally or by anthropogenic factors. Changes on abiotic factors such as light intensity, temperature, salinity, $\mathrm{pH}$ and nutrients have great influenced in growth, physiology and also in proximate and biochemical components of the seaweed $[8,9,10]$. It was reported that salinity and $\mathrm{pH}$ have great influence on carrageenan yield from red algae. Salinity affect carrageenan yield in the ionic equilibrium of the cell due to the negative charge in cation-anion balance of polysaccharide. Meanwhile, $\mathrm{pH}$ is responsible for carrageenan function. At low pH, carrageenan may loss its function where the depolymerisation might occur [ 1 , $11]$. Meanwhile, light intensity has great influence on growth of the seaweed [12].

The red seaweed Gracilaria, is one of the most extensively studied throughout the world due to its economic importance as source of food and hydrocolloids; agar and carrageenan [13, 14]. Besides, cultivation of this genus was done in few countries such as the Philippines, China and Malaysia due to the growing demand and shortage of supply [15]. This species is favorable as it is fast growing species [16] and has the ability to tolerate wide range of environmental changes [17]. This study was aimed to determine the growth rate and carrageenan yield of Gracilaria manilaensis under different salinities and $\mathrm{pH}$ conditions. Result of this study provides important information on the best growth condition and production of carrageenan yield for $G$. manilaensis.

\subsection{EXPERIMENTAL}

\subsection{Sample Collection}

G. manilaensis was collected from Pantai Merdeka, Kedah. The seaweed was acclimatized for a week under the following conditions; $27^{\circ} \mathrm{C}, 23$ psu and 12 $\mathrm{h}$ : $12 \mathrm{~h}$ light: dark. Nutrient concentration of the seawater was determined to quantify the concentration of nutrient present in the seawater.

\subsection{Experimental G. manilaensis Culture}

A series of $3 \times 3$ factorial experiments consisting of light intensity of 500 lux with three $\mathrm{pH}$ values of 7.6, 7.8 and 8.0 and three salinities values of 15,20 and 25 psu were conducted simultaneously in a laboratory. About $4 \mathrm{~g}$ (fresh weight) of Gracilaria was cultured in $500 \mathrm{~mL}$ flask containing $300 \mathrm{~mL}$ of filtered seawater. To maintain the ambient nutrient concentration, a certain amount of nutrient was added every day. Seaweeds were gently aerated to facilitate nutrient uptake. The experiments were performed in triplicate for the duration of three weeks and the seaweed was weighted weekly.

\subsection{Measurement of Growth Rate}

The growth rate was measured as specific growth rate (SGR), expressed as the percentage increase of weight per day according to formula by [18].

$$
S G R=\ln \left(m_{1} / m_{0}\right) * 100 / \dagger
$$

Where $m_{1}$ refer to the final weight and $m_{0}$ is the initial weight and $t$ is time in days.

\subsection{Estimation of Carrageenan Content}

Seaweeds were washed with tap water and cut into $\pm 1 \mathrm{~cm}$ length. Then, it was sun dried to constant weight $(A)$. The seaweeds were kept in dry state in airtight container until the carrageenan analysis was done.

The clean seaweeds were soaked in distilled water for 15 minutes. After that, the seaweed and water were separated by filtration using filter paper Whatman no.1. For the extraction, a known amount of water used as solvent was heated in a beaker. The beaker was placed and heated inside a water bath. When the temperature reached $85^{\circ} \mathrm{C}$ the seaweed was added. The mixture was stirred at $275 \mathrm{rpm}$. The constant ratio of seaweed sample and volume of solvent that is $1 \mathrm{~g}$ : $50 \mathrm{~mL}$ was maintained by adding hot water. The extraction was stopped after 45 minutes. Filtrate was then separated from residue using filter cloth and cold $\left(5^{\circ} \mathrm{C}\right)$ ethanol $(90 \% \mathrm{w})$ was immediately poured into the extract until precipitation showed. This process was done by stirring gently by hand for 30 minutes. The precipitated carrageenan was collected and oven dried at $50{ }^{\circ} \mathrm{C}-60^{\circ} \mathrm{C}$ to a constant weight (B). Farmed $G$. manilaensis was used as control and the carrageenan yield was also determined.

Carrageenan yield was quantified as ratio of dried carrageenan weight (B) to dried seaweed weight $(A)$. 


\subsection{Statistical Analysis}

The significant different between each treatment was analyzed using two-way ANOVA. The relationship between growth rate and carrageenan contents were determined using Pearson correlation coefficient.

\subsection{RESULTS AND DISCUSSION}

Figure 1 showed the mean growth rate of $G$. manilaensis at different salinities and $\mathrm{pH}$. Overall, the mean rate ranges from $0.3 \pm 0.1 \mathrm{~g}$ /days to $1.3 \pm 0.2$ g/days. At salinity (a) 15 psu, the highest growth rate was at $\mathrm{pH} 7.6$ with $1.3 \pm 0.2 \mathrm{~g}$ /days and $\mathrm{pH} 8.0$ showed the lowest growth rate with $0.4 \pm 0.5 \mathrm{~g} /$ days. For salinity (b) $20 \mathrm{psu}$, the highest growth rate was demonstrated at $\mathrm{pH} 7.6$ and 7.8 and lowest at $\mathrm{pH} 8.0$ with $0.9 \pm 0.3 \mathrm{~g} /$ days, $0.9 \pm 0.6 \mathrm{~g} /$ days, and $0.3 \pm 0.1$ g/days respectively. The highest growth rate at salinity (c) $25 \mathrm{psu}$ recorded at $\mathrm{pH} 7.8$ with $1.1 \pm 0.4$ g/days while the lowest growth rate was $0.8 \pm 0.3$ g/days at $\mathrm{pH} 8.0$.

For the carrageenan content, the yield of cultured species was found higher than the control. Carrageenan content of $G$. manilaensis collected from the farm was $50.2 \pm 10.9 \%$. Carrageenan yield of the cultured samples ranges from $61.3 \pm 4.9 \%$ to $91.7 \pm 14.4 \%$. Figure 2 showed carrageenan yield of G. manilaensis at different salinities. At salinity (a) 15 psu, the highest carrageenan content was at $\mathrm{pH} 8.0$ whereas the lowest was at $\mathrm{pH} 7.6$. The percentages of carrageenan recorded at this $\mathrm{pH}$ were $78.3 \pm 20.2$ $\%$ and $66.7 \pm 16.7 \%$ respectively. For salinities (b) 20 psu, the highest carrageenan content was observed at $\mathrm{pH} 7.8$ with $88.9 \pm 19.2 \%$ while the lowest was at $\mathrm{pH}$ 7.6 with $71.7 \pm 7.7 \%$. At salinity of (c) $25 \mathrm{psu}$, the highest carrageenan content was observed at $\mathrm{pH}$ 8.0 with $91.7 \pm 14.4 \%$ and $\mathrm{pH} 7.8$ showed the lowest carrageenan content with $61.3 \pm 4.9 \%$. a)

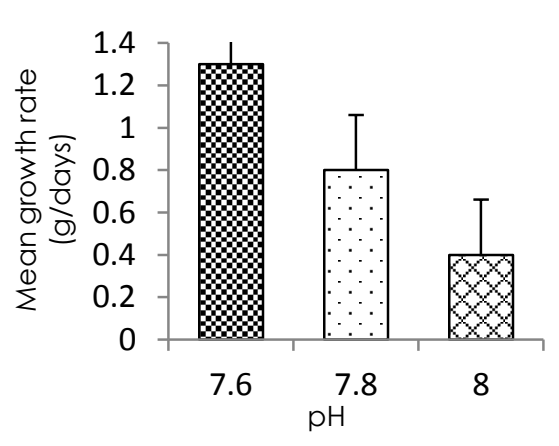

b)

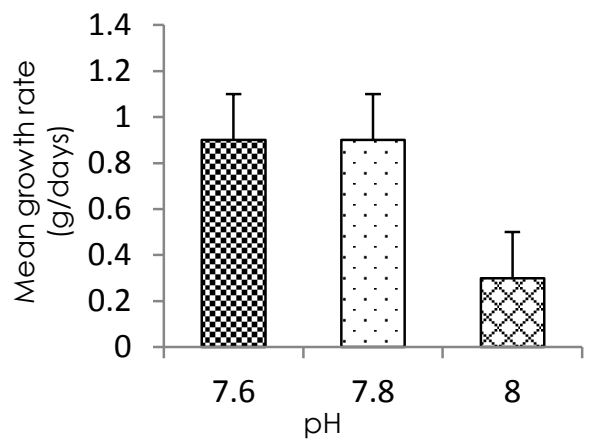

c)

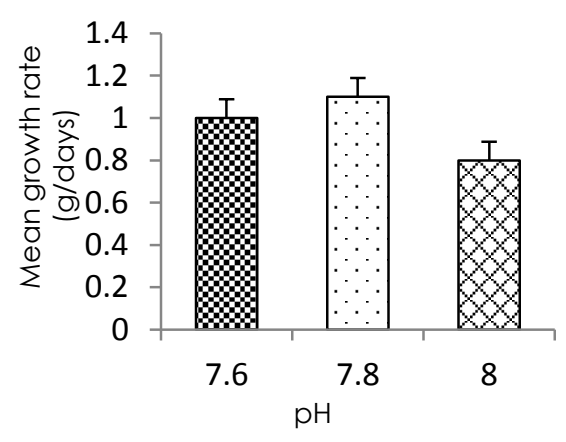

Figure 1 Mean growth rate of G.manilaensis at different salinities (a) 15 psu. (b) 20 psu. (c) 25 psu for different pH 
(a)

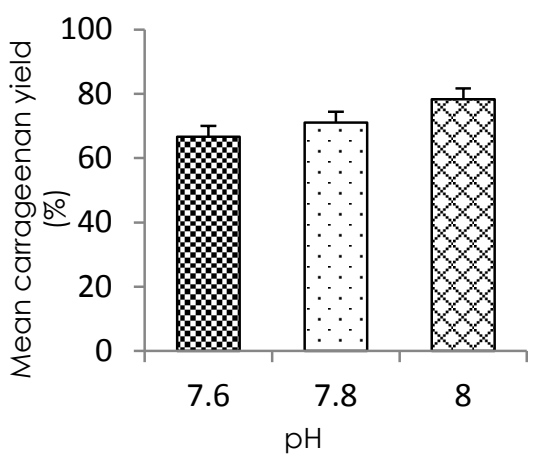

(b)

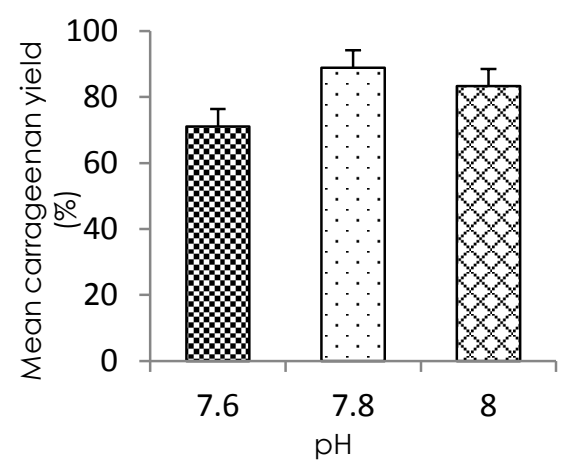

(c)

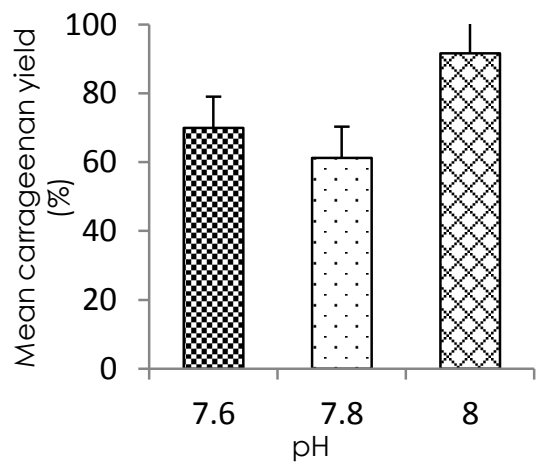

Figure 2- Mean carrageenan yield of G.manilaensis at different salinities (a) 15 psu. (b) 20 psu. (c) 25 psu for different pH

Based on the statistical analysis, there is a significant difference between $\mathrm{pH}$ and growth rate $(p<0.05)$ but not significant was found with salinities $(p>0.05)$. Based on this study, G.manilaensis grows best at $\mathrm{pH} 7.6$ and 7.8 and can be cultured at a broad range of salinity; 15 psu up to 25 psu. At pH 8.0 the lowest growth yield was observed at all salinities. However, study done by [19] on another species of Gracilaria revealed that salinity is positively correlated with growth.

For the carrageenan yield, no significant difference was observed between $\mathrm{pH}$ and salinities $(p>0.05)$. Study by [20] showed that carrageenan yield of Kappaphycus alvarezii, a red algae has also shown a negative correlation with salinity. Maximum carrageenan yield was recorded at salinity range of 24-30\%.

Comparing between growth rate and carrageenan yield, negative correlation was recorded in this study. Similar relationship has also been reported for K. alvarezii [19]. This indicates that the carrageenan yield depends on different environmental condition as observed in this study.

There have been numerous studies on physiological and biological responses of red algae such as Gracilaria spp. to abiotic factors such as light intensity, $\mathrm{pH}$, salinity, temperature [22, 23]. This showed that environmental parameters play essential role in the growth and carrageenan contain. As recorded in this study, a significant difference $(p<0.05)$ of carrageenan yield was found between cultured seaweed and control. This information is essential in order to culture $G$. manilaensis for different purposes; either aimed to have high biomass or produce high carrageenan for industrial purposes.

\subsection{CONCLUSIONS}

Result of this study shows that G. manilaensis has high carrageenan content. Both yield and growth rate are influenced by $\mathrm{pH}$. This indicates that under different environmental condition the carrageenan content of Gracillaria can be manipulated. However, there is no positive relationship between growth rate and carrageenan yield. Therefore, culture of $G$. manilaensis should be cascaded according to the needs, the growth or carrageenan content.

\section{Acknowledgement}

This research was supported by Fundamental Research Grant Scheme fund (FRGS 14-134-0375). The authors wish to express their gratitude to the laboratory staff of Institute of Oceanography and Maritime Study (INOCEM), Kulliyyah of Sience, International Islamic University Malaysia and also to Dr Misni from University Sains Malaysia for numerous helps.

\section{References}

[1] Necas, J. and Bartosikova, L. 2013. Carrageenan: A Review. Veterinarni Medicina. 58: 187-205.

[2] Pangestuti, R. and Kim. S. K. 2014. Chapter SevenBiological Activities of Carrageenan. Advances in Food and Nutrition Research. Academic Press. 72: 113-124.

[3] Campo, V. L., Kawano, D. F., da Silva, D. B. and Carvalho, I. 2009. Carrageenans: Biological Properties, Chemical Modifications and Structural Analysis-A Review. Carbohydrate Polymers. 77: 167-180.

[4] Bezerra, A. F. and Marinho-Soriano, E. 2010. Cultivation of the Red Seaweed Gracilaria birdiae (Gracilariales, Rhodophyta) in Tropical Waters of Northeast Brazil. Biomass and Bioenergy. 34: 1813-1817.

[5] Carlsson, A., van Beilen, J. B., Möller, R. and Clayton, D. 2007. Micro- and Macroalgae: Utility for Industrial Applications. Bowles, D. (Ed.). Outputs from the EPOBIO Project. CPL Press, Berks, UK.

[6] Bixler, H. J. and Porse, H. 2011. A Decade of Change in the Seaweed Hydrocolloids industry. Journal of Applied Phycology. 23: 321-335.

[7] Cirik, S.., Cetin, Z., Ak, İ., Cirik, S., and Göksan, T. 2010. Greenhouse Cultivation of Gracilaria verrucosa (Hudson) Papenfuss and Determination of Chemical Compositionoint. Turkish Journal of Fisheries and Aquatic Sciences. 10(4). 
[8] Orduña-Rojas, J., Robledo, D. and Dawes, C. J. 2002. Studies on the Tropical agarophyte Gracilaria cornea J. Agardh (Rhodophyta, Gracilariales) from Yucatan, Mexico. I. Seasonal Physiological and Biochemical Responses. Botanica Marina. 45: 453-458.

[9] Francavilla, M., Franchi, M., Monteleone, M. and Caroppo, C. 2013. The Red Seaweed Gracilaria gracilis as a Multi Products Source. Marine Drugs. 11: 3754-3776.

[10] Harley, C., Anderson, K., Demes, K., Jorve, J., Kordas, R., Coyle, T. and Graham, M. 2012. Effects of Climate Change on Global Seaweed Communities. Journal of Phycology. 48: 1064-1078.

[11] de Góes, H. G. and Reis, R. P. 2012. Temporal Variation of The Growth, Carrageenan Yield and Quality of Kappaphycus alvarezii (Rhodophyta, Gigartinales) Cultivated at Sepetiba Bay, southeastern Brazilian coast. Journal of Applied Phycology. 24: 173-180.

[12] Raikar, S. V., lima, M., and Fujita, Y. 2001. Effect of Temperature, Salinity and Light Intensity on the Growth of Gracilaria spp. (Gracilariales, Rhodophyta) from Japan, Malaysia and India. Indian Journal of Marine Sciences. 30: 98-104.

[13] Mensi, F., Ksouri, J., Seale, E. G. and Romdhane, M. S. 2011 Modeling Laboratory Culture of Gracilaria verrucosa (Hudson) Papenfuss According to Nutrients Concentrations and Salinities Levels. Bulletin Institut National Science and Technology Mer de Salammbo. 38: 113-121.

[14] Hong, D. D., Hien, H. M. and Son, P. N. 2007. Effect of Irradiation on the Protein Profile, Protein Content, and Quality of Agar from Gracilaria asiatica Zhang et Xia (Rhodophyta). Journal of Applied Phycology. 19: 809-815.

[15] Msuya, F. E. 2004. The Influence of Culture Regimes on the Performance of Seaweed Biofilters in Integrated Mariculture. Thesis submitted for the degree "Doctor of Philosophy" To Senate of Tel-Avi University.
[16] Jayasankar, R., Ramakrishnan, R., Nirmala, K. and Seema, C. 2005. Biochemical Constitutents of Gracilaria Edulis Cultured From Spores. Seaweed Research and Utilisation. 1 \& 2: $39-44$

[17] Phooprong, S., Ogawa, H. and Hayashizaki, K. 2008. Photosynthetic and Respiratory Responses of Gracilaria vermiculophylla (Ohmi) Papenfuss Collected from Kumamoto, Shizuoka and Iwate, Japan. Journal of Applied Phycology. 20: 743-750.

[18] Lobban, C. S., and Harrison, P. J. 1994. Seaweed Ecology and Physiology. Cambridge University Press.

[19] Bunsom, C., and Prathep, A. 2012. Effects of Salinity, Light Intensity and Sediment on Growth, Pigments, Agar Production and Reproduction in Gracilaria tenuistipitata from Songkhla Lagoon in Thailand. Phycological Research. 60: 169-178.

[20] Orbita, M. L. S. 2013. Growth Rate and Carrageenan Yield of Kappaphycus alvarezii (Rhodophyta, Gracilariales cultivated in Kolambugan, Lanao del Norte, Mindanao, Philippines. Advances in Agriculture \& Botanics International Journal of the Bioflux Society. 5: 128-139.

[21] Hayashi, L., de Paula, E. J., and Chow, F. 2007. Growth Rate and Carrageenan Analyses in Four Strains of Kappaphycus alvarezii (Rhodophyta, Gigartinales) farmed in the subtropical waters of São Paulo State, Brazil. Journal of Applied Phycology. 19: 393-399.

[22] Chirapart, A., Munkit, J., and Lewmanomont, K. 2006. Changes in Yield and Quality of Agar from the Agarophytes, Gracilaria fisheri and G. tenuistipitata var. livi cultivated in earthen ponds. Kasetsart J (Nat Sci). 40: 529-540.

[23] Skriptsova, A. V., and Nabivailo, Y. V. 2009. Comparison of Three Gracilarioids: Growth Rate, Agar Content and Quality. Journal of Applied Phycology. 214: 443-450. 